Transformational leadership and innovation: the mediating role of knowledge sharing amongst higher education faculty

\author{
Al-Husseini, S \\ http://hdl.handle.net/10026.1/13686
}

10.1080/13603124.2019.1588381

International Journal of Leadership in Education

Taylor \& Francis (Routledge)

All content in PEARL is protected by copyright law. Author manuscripts are made available in accordance with publisher policies. Please cite only the published version using the details provided on the item record or document. In the absence of an open licence (e.g. Creative Commons), permissions for further reuse of content should be sought from the publisher or author. 


\title{
Transformational Leadership and Innovation: The Mediating Role of Knowledge Sharing amongst Higher Education Faculty
}

\author{
Sawasn Al-husseini ${ }^{\mathrm{a}}$, Ibrahim Elbeltagi ${ }^{\mathrm{b} 1}$ and Jonathan Moizer $^{\mathrm{b}}$ \\ ${ }^{a}$ Materials Management department, Institute of Administration - Rusafa, Middle Technical \\ University, Baghdad, Iraq \\ ${ }^{\mathrm{b}}$ Plymouth Graduate School of Management, Plymouth University, Plymouth, UK \\ ${ }^{1}$ Deceased
}

\begin{abstract}
Transformational leadership has been acknowledged as an important influencing factor in knowledge management and innovation systems across a range of industries. However, there is a lack of research linking transformational leadership, knowledge sharing, and innovation within higher education, specifically within developing countries such as Iraq.

This research seeks to examine the linkages between transformational leadership, knowledge sharing and innovation in higher education. The study involved surveying 250 academic staff based in Iraqi public universities. A model was developed and tested using structural equation modelling. A positive direct impact was found amongst transformational leadership, knowledge sharing and innovation. Moreover, knowledge sharing was identified as a mediator between transformational leadership and innovation. The implications of the findings for higher education institutions are discussed.
\end{abstract}

Keywords: knowledge sharing, knowledge management, transformational leadership, innovation, higher education, developing.

\section{Introduction}

The higher education (HE) sector globally is experiencing rapid change coupled with an increased demand for quality educational delivery (Mathew, 2010). These external pressures are forcing the sector to become more efficient, effective and innovative (Herbst \& Conradie, 2011).

Knowledge and knowledge sharing are significant resources and capabilities that can underpin competitive advantage and are key to enhancing innovation (Von Krogh, Nonaka, \& Rechsteiner, 2012).

Knowledge management and the promotion of knowledge sharing within organisations are important to group learning, as they help to convert tacit knowledge embedded within individuals into explicit knowledge (Von Krogh et al., 2012). Transformational leadership can be a determinant of knowledge sharing and innovation, as this leadership style can result in goal directed behaviour exhibited by followers, enhancing organisational performance and innovation (Bass \& Riggio, 2012).

$\mathrm{HE}$ in Iraq is also facing rapidly changing challenges that require extraordinary leadership. The country is making great efforts to develop its human resources through education. The aim of its educational policy is to reorganise the education system and link education with its national development plans by emphasising scientific professional and technical studies (Sikhi, 2008). In the past, the level of higher education in Iraq was advanced, it won the UNESCO prize for the best illiteracy-free country, especially due to the endorsement of a law on free education in 1982 (UNESCO, 2004). 
Unfortunately, as a result of armed conflicts and the economic embargo imposed between 1991 and 2003, Iraq was distanced from the rest of the world. Additionally, the lack of security, post2003 forced many academics and scientists to emigrate, causing a loss of academic capabilities. UNESCO (2003) identified an urgent need to regain the capacity and competencies of educational institutions of Iraq. If the education sector in Iraq is to have a global reach, changes to systems, methods, curricula, approaches, and specifically, leadership style is required. Iraqi public Higher Education Institutions require unique rather than traditional leaders, as the latter cannot help them to prosper in the present international educational environment (Zwain, Teong, \& Othman, 2012).

The Ministry of Higher Education and Scientific Research has launched an international strategy for 2012-2020 regarding the reform of the HEIs (MOHESR, 2012). It has adopted a number of approaches for upgrading higher education, stressing the need to achieve sustainable human development and strengthen the quality of higher education. This strategy comprises a number of the main axes, such as the development of curricula and study programmes, encouraging creativity, and distinction in scientific research, and developing academics on all levels. It also includes upgrading the capabilities of the teaching staff in using technology for education and learning. This strategy will only succeed with the active participation of the leaders and academic staff from the various HEIs in Iraq.

Innovation is essential to learning institutions (Smith, 2009); hence, it is important to enhance the delivery of taught courses, improve institutions' problem-solving capabilities and the quality of applied research. The relationships-between transformational leadership and innovation (Nijstad, Berger-Selman, \& De Dreu, 2014; Weng, Huang, Chen, \& Chang, 2015), between transformational leadership and knowledge sharing (Li, Shang, Liu, \& Xi, 2014; Shao, Feng, \& Liu, 2012) and between knowledge sharing and innovation (Leonardi, 2014; Ritala, Olander, Michailova, \& Husted, 2015; Wang \& Wang, 2012) have been widely studied. However, any causal linkages between all these factors has yet to be established.

Noruzy et al. (2013) investigated the relationship between transformational leadership, organisational learning, knowledge management innovation, and performance among Iranian firms, and concluded that leaders undertaking a transformational role, using organisational learning and knowledge management and facilitating innovation improved organisational performance. Whilst these results generated some insights, the study did not consider knowledge sharing as a potential causal factor. According to Zwain et al.(2012) the practice of knowledge management within HEIs in Iraq is still new but the possibility of its acceptance is high.

This study aims to establish whether a structural relationship exists between transformational leadership and faculty innovation through the mediating role of knowledge sharing in Iraqi public universities. To achieve this aim, this paper is organised as follows: the next section presents an exposition of the theoretical background of organisational knowledge sharing and innovation and their linkages to transformational leadership. Next, the previous research on the linkages between these factors is presented. This is followed by an outline of the structural equation modelling method adopted to analyse the hypotheses.

Then the results of the survey of Iraqi faculty are presented. Next, a discussion that summarises and analyses the main findings is provided. The implications of the findings for Iraqi HEIs are considered in the penultimate section. Finally, the conclusion highlights the key contributions of the paper along with recognition of the limitations of the work and future directions for similar research. 


\section{Literature review}

\section{Knowledge and knowledge sharing}

The concept of organisational knowledge has been framed in different ways. Hislop (2013) delineates between two perspectives of knowledge theory, namely possession and practice. The epistemology of possession treats knowledge as something individuals have. It assumes that knowledge is an entity/object they possess and refers to cognitive resources used to improve effectiveness in the workplace. These include knowledge stored in databases, routines or books (Biggiero, 2012). The epistemology of practice, on the other hand, defines knowledge as something people do. Therefore, it refers to knowledge as subjective, negotiated, and practised through social interaction. This knowledge resides in the way people conduct their practices or produce outcomes. A shift occurs from knowledge to knowing.

Researchers acknowledge different types of knowledge; however, the most common distinction is between tacit and explicit knowledge. Tacit knowledge is more complex, subjective and personal and is embedded in people's minds. It is accumulated through study and experiences, and developed through social interaction (Chuang, 2016; Von Krogh et al., 2012). In contrast, explicit knowledge is codified and documented. It is more tangible and easily shared between individuals (Hau, Kim, Lee, \& Kim, 2013). These two kinds of knowledge are complementary, and personal knowledge can become organisational knowledge through the interactions between tacit and explicit knowledge (Von Krogh et al., 2012).

Zheng, Yang, and McLean (2009) described knowledge management as acquisition, sharing, and application. They asserted that innovation and effectiveness is achieved when knowledge sharing is taken into consideration. Hislop (2013) identified knowledge sharing as focal to knowledge management. It is considered to be an indicator of organisational effectiveness.

Mathew (2010) when studying universities, found the existence of knowledge, and the development of a knowledge culture among faculty generates innovation and enhances academic performance. More recently, Tan (2016) identified organisational culture trust and knowledge management systems as determinants of knowledge sharing within Malaysian research focused HEIs.

Hislop (2013) described knowledge sharing as the interaction between implicit and explicit. knowledge relevant to the task at hand. Lin (2007) identified knowledge sharing as involving the carrier and requester of knowledge, while Ardichili, Page, and Wentling (2003) proposed that knowledge sharing includes a supply of and demand for new knowledge. Indeed, knowledge sharing can provide the basis for more radical innovation to occur in organisations (Zhou \& Li, 2012).

For the purpose of this paper, knowledge sharing is defined as a two-dimensional process, as described by (Hooff \& Weenen, 2004), with staff sharing and exchanging tacit and explicit knowledge, with interactions creating new knowledge through the process of knowledge exchange, donation, and collection.

\section{Transformational leadership}

Transformational leadership has received significant attention in the literature (Bass, 1985; Schmitt, Hartog, \& Belschak, 2016). Bass and Riggio (2012) described Transformational leadership as a process in which people are transformed. It involves attempts to make changes that increase organisational effectiveness and the performance of followers, by transforming the latter's personal values and self-concepts.

The theory is based on the assumption that followers need to be respected, appreciated and trusted in order for the leader to gain their loyalty, and that everyone has a contribution to make (Northouse, 2012).

Researchers in the field have argued that transformational leadership generates subordinate commitment, improves performance and encourages more creative problem solving (Mittal \& Dhar, 2015; Yukl, 2013). It emphasises follower's intrinsic motivation, ethical behaviour, the 
development of leadership among team members, and shared vision and goals.

In a higher education environment, transformational leadership can encourage faculty to participate in educational programmes aimed at promoting skills that can then deliver exceptional performance (Pounder, 2009).

According to Bass and Riggio (2012) there are four dimensions to transformational leadership: idealised influence that expresses confidence in the organisational vision, instils admiration, respect, and emphasises accomplishments. Under inspirational motivation, followers are encouraged and impassioned by the goals of the organisation. Through intellectual stimulation, leaders seek new methods of solving problems from followers, motivating them to question assumptions, and encouraging imagination and creativity in rethinking old approaches. By practising individualised consideration style, leaders can build interactive relationships with subordinates and pay special attention to their individual needs. These four behavioural patterns positively affect followers by elevating them to the best they can be, motivated by desire for achievement and self-development.

\section{Innovation}

Innovation provides organisations with the potential to respond and adapt to environmental and technological change. Innovative organisations have the capacity to improve individual and organisational performance, solve problems, and create competitive advantage (Trott, 2008). Innovation can involve developing, implementing, generating, and adopting new ideas, methods, programmes, and policies to achieve organisational goals. Innovation can be key to achieving profitability, including the higher education sector (McClure, 2016). Collective learning can be regarded as an antecedent to innovation (James, Guile, \& Unwin., 2016).

Different types of innovation take place in organisations. For instance, Dewar and Dutton (1986) and Liao, Fei, and Chen (2007) distinguished between radical and incremental innovation. Tidd and Bessant (2011) assert that innovation can be understood through product and process. Daft (1978) focused on technical and administrative innovation. Others such as Walker (2007) and Obendhain and Johnson (2004) have suggested a range of types such as positional, system-based, behavioural, and paradigm innovation.

Product and process innovation can provide organisations with the capability to solve problems, add value, and improve performance (Theyel \& Hofmann, 2015; Trott, 2008). Liao, Fei, and Chen (2007) suggested that these two dimensions could determine an organisation's success or failure. In higher education, product and process innovation can raise educational performance, with educational quality being reliant on both adapting to the changing environment (Obendhain \& Johnson, 2004).

Product innovation is associated with new product development that can help the organisation to achieve its goals (Trott, 2008). It can be measured by profitability and diversity (Tsai, Huang, \& Kao, 2001), the number of products, or the speed of innovation (Hung, Lien, Fang, \& Mclean, 2010). In contrast, process innovation involves new modes of service and its delivery, and the introduction of new equipment and information (Jaskyte, 2004).

\section{Theories and Hypotheses}

\section{Transformational leadership and innovation}

Eisenbei $\beta$ and Boerner (2013) reported that transformational leadership acts as a lever to innovation. To enhance innovation, organisations require commitment and must encourage communication among members. Transformational leaders can encourage followers to act on an organisation's vision in order to foster innovation (Bass \& Riggio, 2012; García-Morales, 2012).

Transformational leaders with idealised influence are able to build employee trust and respect, express confidence in the organisational vision and emphasise the importance of a collective 
sense of the organisation's mission (Yukl, 2013). These characteristics encourage subordinates to work hard and innovate. By practising inspirational motivation, leaders can motivate followers to achieve the required performance by creating a climate of collaboration and teamwork. They shape the vision, gain optimistic commitment to that vision and encourage an appropriate environment for innovation.

By providing intellectual stimulation, transformational leaders encourage the imagination and creativity of their followers, so that they re-examine assumptions and old ways of doing things (Northouse, 2012). When individuals are encouraged to re-think, and know that their ideas are valued, they are more likely to generate innovative ideas (Jung, Chow, \& Wu, 2003). Using individualised consideration, transformational leaders build individual relationships with their followers, and consider their needs, abilities, and aspirations in such a way that facilitates innovation. When leaders provide support and coaching, followers are more willing to innovate (Bass \& Riggio, 2012).

Leadership has been linked to innovation. For instance, Redmond and Mumford (1993) showed that transformational leaders are able to create contexts that motivate followers to innovate, by defining group goals and controlling critical recourses. Amundsen and Martinsen (2015) examining a Norwegian healthcare provider identified strong links between transformational leadership facilitating self-leadership, and the positive impact on employee innovation and creativity. Chang (2012) pointed out that leaders who coach, counsel and train their followers can enhance staff skills and encourage them to attempt new methods of process innovation.

Akbar, Rezaei, \& Roshanak (2015) studying employees of an Iranian university did find that transformational leadership has a positive impact on employee creativity and innovation.

However, these studies did not examine how specific transformational leadership behaviours affect innovation, particularly among staff working on product and process development. Scant empirical research has examined the existence of such links. Certainly, they have not been researched within the context of the higher education sectors of developing countries such as Iraq. Thus, this research specifies the following hypotheses:

H1: Transformational leadership with idealised influence $(\mathrm{Hla})$, inspirational motivation $(H I b)$, intellectual stimulation $(H I c)$, and individualised consideration $(H I d)$ will positively influence product innovation in Iraq's public HEIs.

Transformational leadership, in terms of idealised influence (Hle), inspirational motivation $(H 1 f)$, intellectual stimulation, $(H 1 g)$ and individualised $(H 1 h)$, will positively influence process innovation in Iraq's public HEIs.

\section{Transformational leadership and knowledge sharing}

Hislop (2013) suggests that knowledge sharing is central to organisational competitiveness. According to Bollinger and Smith (2001) organisational culture enables members to work together and share knowledge. Fullwood, Rowley, and Delbridge (2013) found this to be the case within a UK HEI. Mansor, Mustaffa, and Salleh (2015) also identified culture as an influencing factor for knowledge sharing in a Malaysian public university.

Transformational leaders with idealised influence tend to emphasise the importance of a collective sense of the organisation's mission (Bass \& Riggio, 2012). When members feel that their leaders have confidence in them and appreciate their efforts they will be more willing to give opinions and to share knowledge (Nguyen \& Mohamed, 2011). Employees working under leaders practising inspirational motivation are encouraged to achieve the organisational vision because of the individual and team spirit that is created and are inspired to lead task-oriented commitment through sharing that vision (Braun, Peus, Weisweiler, \& Frey, 2013).

When transformational leaders facilitate the search for new opportunities and the establishment of a shared vision, employees' sense of responsibility will increase along with knowledge sharing (Bass \& Riggio, 2012). Leaders using individualised consideration are aware of their followers' needs and concerns and develop their strengths through coaching and consulting, 
providing advice and hands-on guidance to their followers (Tims, Bakker, \& Xanthopoulou, 2011).

Nguyen and Mohamed (2011) found transformational leadership has more of an effect than transactional leadership on knowledge management. A survey conducted by Chen and Barnes (2006) of managers in Taiwanese and American firms showed that TL is critical for knowledge sharing, with leaders who encourage and enhance problem solving and pay more attention to their employees being more likely to improve knowledge sharing. A study by Li et al. (2014) across Chinese firms found that facilitating individual focused leadership was a determinant of knowledge sharing.

Whilst the above studies have evidenced strong relationships between leadership and knowledge sharing they have not fully examined the mechanisms through which transformational leadership shapes employee performance and behaviour. Jahani, Ramaya, and Effendi (2011) called for leadership research to explain how knowledge sharing can be enhanced in public organisations situated in developing countries such as Iraq. Thus, this research proposes the following hypotheses:

H2: Transformational leadership, in the form of idealised influence $(H 2 a)$, inspirational motivation $(\mathrm{H} 2 b)$, intellectual stimulation $(H 2 c)$, and individualised consideration $(H 2 d)$ will positively influence knowledge sharing in Iraq's public HEIs.

\section{Knowledge sharing and innovation}

The knowledge-based view recognises that knowledge is a valuable resource of organisations and a central to organisational innovation (Mearns, 2012; Von Krogh et al., 2012). Innovation depends on employees' knowledge, skills and experiences in the value creation process (Wang \& Wang, 2012). Since knowledge is embedded within individuals, it is necessary to share among organisational members so as to establish new routines to help solve problems (Von Krogh et al., 2012). When tacit knowledge is shared it converts into explicit knowledge, collective learning is generated, which in turn develops the knowledge available to the organisation. Knowledge sharing can generate new ideas for developing products, services and processes (Carmeli, 2013; Wang \& Wang, 2012).

Previous studies have reported that knowledge sharing is an antecedent of innovation and change. Lin and Lee (2005) found that firms applying strategies sharing technological knowledge with competitors achieved higher performance than those that did not. Chen, Huang, and Hsiao (2010) identified a positive relationship between knowledge creation and sharing, and innovation. Andreeva and Kianto (2013) highlighted that knowledge creation can predict product, management, and marketing innovation. Jiang and Chen (2016) examined the relationship between transformational leadership, knowledge sharing and innovation across teams working on knowledge intensive tasks, finding a strong relationship between knowledge sharing and innovation.

Although these studies have looked at the relationship between knowledge sharing and innovation, they do not touch on knowledge processes and their impact on university faculty's' product and process innovation. There is a need for research addressing the practical difficulties of knowledge sharing for product and process innovation within developing country's universities, particularly the Iraqi environment; thus, this research presents the following hypotheses: H3: Knowledge sharing positively influences $(\mathrm{H} 3 \mathrm{a})$ product and $(\mathrm{H} 3 b)$ process innovation in Iraq's public HEIs.

\section{The mediating effect of knowledge sharing}

As discussed earlier, the linkages between transformational leadership and knowledge sharing $(H 2)$, and knowledge sharing and innovation ( $H 3$ ), suggest that transformational leadership affects innovation via its effects on knowledge sharing. Enhancing product and process innovation requires leaders to cultivate respect, admiration and commitment. 
Knowledge is key to innovation, and innovation is a process of defining problems and creating new knowledge to solve them. Tacit knowledge is embedded in different individuals and has to be converted into explicit knowledge. Knowledge sharing processes followed by organisational members help them to convert the knowledge, create new routines and mental models, and solve problems (Von Krogh et al., 2012). Transformational leadership can help to lever knowledge and exchange the skills and experiences that reside in individual minds. It can encourage and promote a knowledge sharing culture through idealised

influence by instilling admiration and respect. Through inspirational motivation, leaders can create team spirit by encouraging commitment, communication (Bass \& Riggio, 2012) and psychological empowerment (Han, Seo, Li, \& Yoon, 2016).

Using individualised consideration, leaders are able to pay special attention to followers, encouraging them to solve problems. When knowledge can be shared among organisational members through donating and collecting, knowledge will be made available, and this will help to generate new ideas, which in turn can improve product and process innovation (Wang \& Wang, 2012).

Although transformational leadership may affect innovation directly, research has suggested that the direct effects may be too complex to isolate (Srivastava, Bartol, \& Locke, 2006).

Insufficient attention has been given to the mechanisms that may explain these relationships, and research is needed to address and understand the processes through which transformational leadership influences innovation. Accordingly, this research argues that knowledge sharing plays a mediating role in the relationship between transformational leadership and innovation (as outlined in Figure 1) and the following hypothesis is proposed:

H4: Knowledge sharing will positively mediate the impact of the transformational leadership style on innovation in Iraq's public HEIs.

\section{INSERT FIGURE 1 ABOUT HERE}

\section{Method}

\section{Measurements of the constructs}

A survey of faculty in Iraqi public HEIs was conducted to test the hypothetical model. A selfadministered questionnaire was developed. The questionnaire was divided into three sections, with the items in each section relating to the study's constructs. Respondents used a 5-point Likert Scale for all items, where $1=$ strongly disagree and $5=$ strongly agree to indicate their opinions about the relationships between transformational leadership, knowledge sharing and innovation.

Within the survey, knowledge sharing was measured using 12 items reflecting the exchange of teaching related knowledge, experiences, and skills among faculty through the donating and collecting of knowledge. These items were developed from Hooff and Weenen's (2004) study of these relationships.

Transformational leadership was measured using 21 items taken from a multi-factor questionnaire developed by Bass and Avolio (2000) This included four constructs:

1) Idealised influence reflected leaders encouraging their members of staff to have faith and respect in themselves and their colleges;

2) Inspirational motivation captured leaders' attempts to stimulate members of staff by involving them in the shared vision for the university;

3) Intellectual stimulation denoted the promotion of learning, and creativity;

4) Individualised consideration reflected the idea of leaders satisfying members of staff by advising them and listening to their individual needs. 
Thirteen items were used to measure innovation, in terms of accepting or developing new ideas around products and processes. These items were developed from two prior studies; (Daft, 1978; Perri, 1993). In this component of the questionnaire, product innovation referred to the degree to which faculty accepted, developed, and implemented new products such as research projects and curricula; while process innovation reflected the use of new methods of service delivery through the development and use of new technology, and the implementation of rewards systems for faculty (See Appendix).

\section{Data collection}

By the year 2011, the Ministry of Higher Education and Scientific Research coordinated 69 public universities and technical institutes spread across the country, in addition to five subject discipline research institutes. These universities educate students to Batchelor, Masters and PhD level degrees (MOHESR, 2012).

The organisational structure for Iraqi public universities is as follows. The Council of the University is the highest administrative and scientific body of each HEI. It is headed by a vicechancellor, with membership comprising of the university president, deans, the deputies of the vice-chancellor and two members of teaching staff who are selected by the president in conjunction with the preferences of university staff. They serve on the council for a two-year term. Reporting to the Council of the University is the College Council, which is the highest administrative and scientific body of the college, and whose membership consists of the dean, the deputy dean, the heads of the scientific departments or branches, and the directors of any research centres linked to the college. The Scientific Department is the principal scientific unit within the university. The Department Council is run by the head of the scientific department and their assistants, who are responsible for managing the department. They oversee pedagogic developments, curriculum design, staff resourcing, student affairs, student project supervision, research project selection and the appointment of visiting faculty. They work closely with faculty to achieve this.

A convenience sampling approach was used to find universities willing to participate in the study. The population size is 4,523 for the eight public HEIs in Baghdad. Thus, a required precision level of $7 \%$ and a $95 \%$ confidence level gives a required sample of 200 staff members according to Glenn (2003). Hair, Black, Babin, and Anderson (2010) asserted that, in SEM, the sample size should be greater than 100 to provide satisfactory statistical power. Thus, according to the results above, the sample size was deemed acceptable for the current study.

The questionnaires were distributed using the delivery and collection method. A total of 600 questionnaires were administered with $37863 \%$ returns, of which 250 were deemed useable, giving a usable response rate of $42 \%$. The characteristics of the respondents are provided in Table 1. Females represented $54.4 \%$ of respondents and males, $45.6 \%$. Regards age profile, tenure and academic position, respondents were asymmetrically distributed across the different categories.

\section{INSERT TABLE 1 ABOUT HERE}

\section{Findings}

As this research aimed to examine the impact of transformational leadership on innovation through the mediating role of knowledge sharing, structural equation modelling-SEM was used as a suitable method to estimate these complex cause-effect relationships through analysis of the questionnaire response. This comprised of two steps; creating a measurement model to 
evaluate the convergent validity of the constructs, followed by building a structural model to test and evaluate the direct and indirect effects.

\section{Measurement model}

Seven constructs: idealised influence, inspirational motivation, intellectual stimulation, individualised consideration, knowledge sharing, product innovation and process innovation were measured using 32 items. The model was evaluated using convergent validity through confirmatory factor analysis-CFA. Convergent validity was tested by investigating factor loadings of 0.5 or higher. Additionally, the average variance extracted -AVE measure was used with items scoring factor loadings of more than 0.5 retained. Fourteen items were reported as below the factor loading and AVE cut-off values of 0.5, and therefore were deleted from the scale to improve the model (as they were unable to make good contributions to their predicted constructs.

Reliability was assessed separately for each dimension included in the model, based on the Cronbach's alpha and composite reliability (CR) scores, each of which should exceed 0.7 to be statistically reliable (Hair et al., 2010). Table 2 shows that the convergent validity and internal reliability are satisfactory for all constructs since all factor loadings, CR and AVE values are acceptable and significant.

\section{INSERT TABLE 2 ABOUT HERE}

The data constructs were found to be empirically distinct and the discriminant validity was statistically confirmed. Table 3 displays the means and standard deviations by construct. Additionally, it shows that the variances extracted from the constructs were greater than any of the squared correlations amongst the items.

\section{INSERT TABLE 3 ABOUT HERE}

The following indices, as shown in Table 4 were used to evaluate the measurement model: fit indices $\chi^{2} / \mathrm{df}$, the goodness of fit index, and the root mean squared error of approximation, incremental fit measures, normed fit index, and comparative fit index.

\section{INSERT TABLE 4 ABOUT HERE}

\section{Structural model}

The goodness of fit indices demonstrated adequate levels of fit for the model, as evidenced in Table 5. The SEM results for the direct effect are robust and statistically significant.

\section{INSERT TABLE 5 ABOUT HERE}

$H 1(a-h)$ are concerned with the effect of transformational leadership on product and process innovation. The Table shows an overall effect of 0.289 for product innovation, with sub-effects of $0.214,0.263,0.301$, and 0.352 for $H 1(a-d)$, and an overall effect of 0.301 on process innovation, with sub effects of $0.243,0.265,0.307$ and 0.354 for $H 1(e-h)$, while the effect of transformational leadership on innovation was 0.295 . The significance levels calculated were all below the $5 \%$ level, confirming that $H 1(a-h)$ are fully supported. 
$H 2$ concerns the direct effect of transformational leadership on knowledge sharing. Table 5 shows an overall effect size of 0.629 , with respective sub-effects of $0.570,0.524,0.790$ and 0.635 . The result was statistically significant at the $5 \%$ level, thus $H 2$ is confirmed. The effect of knowledge sharing on the combined product and process innovation has a value of 0.723 , with sub-effects of 0.701 and 0.745 . This result was also significant at the 5\% level, providing support for $H 3(a-b)$.

Turning to the indirect effect, Table 6 and Figure 2 show knowledge sharing exhibiting a partial mediating effect on the relationship between transformational leadership and innovation. Both the direct and indirect effects of transformational leadership on innovation are significant at the $5 \%$ level, confirming $\mathrm{H} 4$ with a stronger indirect effect of 0.493 over the direct effect of 0.295 .

\section{INSERT TABLE 6 ABOUT HERE}

\section{INSERT FIGURE 2 ABOUT HERE}

\section{Discussion}

This research has proposed a SEM to examine the mediating effect of knowledge sharing on the relationship between transformational leadership and innovation within Iraq's public HEIs. The SEM supports the hypothesised relations, as discussed below. Idealised influence $(\mathrm{HIa})$ and $(\mathrm{Hle})$ is found to be positively related to product and process innovation. The results indicate that leaders in Iraqi universities possess the quality of idealised influence through holding the respect and faith of their faculty. Faculty are more innovative as a result of undertaking curricula development and training programmes, research projects, and adopting new technology, when their leaders trust them and create a sense of pride amongst them. The findings of this study are congruent with the assertion that leaders with idealised influence enable a change in cultural values, leading to greater product and process innovation (Vaccaro, Jansen, Bosch, \& Volberda, 2012).

Inspirational motivation $(H 1 b),(H 1 f)$ is a behaviour by which leaders encourage organisational learning and shape a vision that enables their organisation to be more innovative (Bass \& Riggio, 2012). The findings suggest the faculty surveyed prefer leaders with vision. This style of leadership helps public HEIs in Iraq to go through destabilising phases that are part of the change process needed to meet long-term goals. Such leaders can make faculty feel valued and help them recognise the importance of the work they do. Previous research has found that leaders with vision create environments where knowledge is shared, which promotes innovation (Chang, 2012). The results of this research lends support to that assertion within Iraqi HEIs. Transformational leaders using intellectual stimulation $(\mathrm{HlC})$ and $(\mathrm{Hlg})$ are most likely to enhance idea generation and exploratory thinking. The results suggest that the faculty surveyed feel that their leaders intellectually stimulate their creative thinking. Thus, they are encouraged to look at existing problems in new and creative ways and are made to feel that their contributions are valued. Consequently, they are open to new approaches to designing courses, research projects, and curricula, to attending training programmes, and adopting new technology in their work. These findings are inconsistent with Rafferty and Griffin's (2004) findings based on a study of 1398 employee in Australian public organisations, which showed that leaders with vision did not always have a positive influence on followers' innovation.

However, the results agree with the assertions of others (Alzawahreh, 2011; Sagnak, 2012) who have suggested that leaders exhibiting intellectual stimulation are necessary for innovation, particularly product and process. 
The last of the transformational leadership dimensions is individualised consideration $(H 1 d)$, (HIh). By considering the ideas of individual faculty, a leader can develop an expanded source of knowledge that can help with collective problem solving. These results indicate that faculty work harder and generate more innovative ideas when they receive special attention and support. The findings also reveal that transformational leaders displaying individualised consideration provide faculty with suitable coaching, enabling them to innovate with teaching and administrative activities. These findings confirm prior literature suggesting that leaders who use consulting, delegating, and supporting behaviour are able to foster the generation and application of ideas by employees (Sagnak, 2012).

The results of the SEM supported the hypothesised relations between transformational leadership and knowledge sharing $(H 2)$. This research found that idealised influence was positively related to knowledge sharing (H2a). Barnett, McCormick, and Conners (2001) noted that transformational leaders with this style can build a trust-based culture within educational institutes, an antecedent of knowledge sharing. Followers who feel trusted by their leaders are not only willing to listen to others but are also able to absorb knowledge from them, with the result that they tend to become interested in sharing knowledge themselves. These findings suggest that faculty in public HEIs in Iraq believe that their leaders encourage them to donate and collect knowledge through exchanging views, using peer support for developing learning technologies and skills development. These results are consistent with Mohamed (2012) who pointed out that leaders who instil respect, and trust are able to facilitate knowledge acquisition and sharing among organisational members.

Transformational leaders exhibiting inspirational motivation $(\mathrm{H} 2 \mathrm{~b})$ are enthusiastic and optimistic. The results support the proposition that inspirational motivation directly encourages knowledge sharing processes among faculty in Iraqi HE by arousing team spirit and stimulating them to envisage attractive futures for their universities. This style can help faculty to connect with and support a shared vision.

In terms of intellectual stimulation $(\mathrm{H} 2 \mathrm{c})$, literature indicates that transformational leaders can facilitate the search for new approaches and the establishment of a common vision. The findings demonstrate that leaders in Iraqi public HE can create opportunities that stimulate and encourage KS within faculty by challenging them to find solutions to problems using technology and seek new approaches to curricula development.

Leaders use individualised consideration $(\mathrm{H} 2 \mathrm{~d}$ ) when they pay attention to the needs of their followers and develop their strengths through coaching activity. This research has shown that the faculty surveyed feel that their leaders encourage them to share knowledge by coaching them to communicate effectively with each other and listen to suggestions regarding teaching and administration. These results supplement the earlier findings of Jahani, Ramaya, and Effendi (2011) who indicated that leaders who coach and offer consulting contribute to positive knowledge management practices.

With regard to the relationship between knowledge sharing and innovation (H3a-b), this research found positive relationships for both product and process innovation. It demonstrated that the faculty in Iraqi public higher education are willing to donate and collect knowledge enabling their universities to improve their products (e.g. research outputs, curricula, and their process innovation (curricula development and adoption of new technology to support academic activity. These results help to validate the assertions of previous studies such as Cheng (2012) who indicated that promoting knowledge sharing practice within educational environments helps faculty to discuss different ideas around curricula design, development and delivery, thus supporting product and process innovation.

The results from the SEM support the mediating role of knowledge sharing in the relationship between transformational leadership and innovation (H4). They show that transformational 
leadership is positively related to knowledge sharing, which in turn is positively related to innovation. The findings also indicate that transformational leaders promote a knowledge sharing culture among their faculty within Iraqi HEIs by practising idealised influence (building trust and admiration, inspirational motivation (encouraging commitment and communication.

intellectual stimulation (seeking new approaches to teaching, and individualised consideration (considering their faculty's needs. Consequently, faculty are willing to donate and collect knowledge, skills, experiences and teaching materials, which in turn lead to new ideas for courses, curricula, research projects, and application of new technology, aiding product and process innovation.

Although previous studies identified that transformational leadership has a direct impact on innovation (Chang, 2012), this research has found no such relationship in the case of Iraq's public HEIs. Table 6 reveals a stronger indirect effect (0.493) over the direct effect (0.295). It is possible that transformational leadership in Iraqi HEIs can create a culture that supports innovation through knowledge sharing instead of having a direct effect on innovation. This finding agrees with the view of Jung, Chow, and Wu (2003) who found that transformational leadership could directly and indirectly enhance innovation. The study results suggest that transformational leadership indirectly enhances product and process innovation by creating an

.organisational culture that supports knowledge sharing

\section{Implications of the research}

This research examined the impact of transformational leadership on academic innovation through the mediating role of knowledge sharing in Iraq's public HEIs. From a theoretical perspective, the research provides additional insight into the relationship between transformational leadership and innovation by applying it to a new theme of study, namely combined product and process innovation within the higher education sector. Iraq is the country which is representative of many developing economies' higher education sectors.

The results confirm that the four components of transformational leadership (idealised influence, inspirational motivation, intellectual stimulation, and individualised consideration influence product and process innovation, and help provide better understanding of the linkages between transformational leadership and innovation. This is important as it demonstrates that transformational leadership can promote the generation of capabilities not developed under the traditional leadership style.

The research strengthens and supports the link between transformational leadership and knowledge sharing among faculty, showing that transformational leadership provides support, and promotes a knowledge sharing culture. This gives an indication as to the most important factors that influence knowledge sharing and provides a clue to how HEIs can promote knowledge sharing activity. The results have clarified specific aspects of transformational leadership (idealised influence, inspirational motivation, intellectual stimulation and individualised consideration) and their impact on knowledge sharing. This information can provide leaders in HEIs with guidance on the style of behaviour required to promote organisational knowledge sharing.

Additionally, the research supports taking a knowledge-based view of organisations, and empirically strengthens the role knowledge sharing plays in enhancing product and process innovation in HEIs. These results generate understanding of how knowledge can contribute to competitive advantage in HEIs. KS is known to transfer individual experiences, knowledge, skills, expertise and information into explicit and organisational assets for better innovation (Von Krogh et al., 2012). Further, this research identifies the types of innovation most affected by knowledge sharing, which can help HEI leaders focus on strategies to stimulate organisational innovation.

The most significant contribution of this research is recognition of the mediating effect of knowledge sharing on the relationship between transformational leadership and innovation. 
These findings support Lin's (2007) study of knowledge sharing processes as key factors to organisational success. In addition, they extend the work of Lin by examining these causal relationships within Iraqi HE.

From a methodological perspective, the study supports and demonstrates the validity and reliability of using a multi-factor questionnaire and the setting of the knowledge sharing and innovation scales within it. This gives a greater accuracy to the results in Iraqi HEIs and provides a valuable example of a methodology that researchers and academics might use to track the extent of transformational leadership, and knowledge sharing and their effects on product and process innovation in other similar research.

The study's findings have implications for academic leaders and policy makers. The results illustrate the importance of transformational leadership in universities, in terms of knowledge sharing and innovation. Therefore, universities should foster the presence of transformational leaders to aid the development of their faculty. Such leadership would give faculty a clear direction and sense of purpose through establishing an environment of mutual trust and respect. Hence, universities should implement transformational leadership courses through which leaders can learn to effectively encourage and intellectually stimulate their faculty.

The important role of knowledge sharing as a mediator variable in the transformational leadership-innovation relationship implies that HEI leaders need to promote knowledge sharing. The findings show that innovation requires faculty to generate and share knowledge. Therefore, leaders should design strategies aimed at encouraging knowledge sharing.

\section{Conclusion, limitations, and future research direction}

Based on 250 questionnaires from Iraqi public universities, SEM was implemented to test the research hypotheses. The findings demonstrate the importance of transformational leadership and knowledge sharing.

The research focused on transformational leadership only in terms of encouraging knowledge sharing with a view to enhancing product and process innovation. This style is usually studied in combination with transactional leadership (Bass, 1985). Thus, future research could explore the impacts of both transformational and transactional leadership to determine which is more influential on product and process innovation. The research was limited to focusing on transformational leadership as an enabler for knowledge sharing and innovation. However, it did not consider all enablers that are critical to knowledge sharing, such as individual characteristics or organisational climate. Future research could study other factors.

Knowledge sharing can result in other outcomes that can lead to competitive advantage (Von Krogh et al., 2012). Examining the impact of knowledge sharing processes on other outcomes such as organisational learning, education quality, academic performance, and staff satisfaction would be interesting themes for future research.

The study was conducted in higher education, and further opportunities exist to explore such relationships in other industries. Moreover, this study was applied in a single developing country, and the findings may not generalise to other developing countries with different economies and societies. Future research could extend the investigation to countries sharing similar structures, culture, and contexts with Iraq. 


\section{References}

Akbar, A. A., Rezaei, S., \& Roshanak, C. (2015). Impact of Transformational and Transactional Leadership Style on Employees. International Journal of Environmental Research, 12(4), $1109-1123$.

Alzawahreh, A. (2011). Transformational leadership of superiors and creativity level among faculty members in Jordanian universities. Journal of Institutional Research South East Asia, 9(1), 125-132.

Amundsen, S., \& Martinsen, Ø. L. (2015). Linking Empowering Leadership to Job Satisfaction, Work Effort, and Creativity: The Role of Self-leadership and Psychological Empowerment. Journal of Leadership \& Organizational Studies, 22(3), 304-323.

Andreeva, T., \& Kianto, A. (2013). Knowledge processes, knowledge-intensity and innovation: A moderated mediation analysis. Journal of Knowledge Management, 15(6), .1016-1034.

Ardichili, A., Page, V., \& Wentling, T. (2003). Motivation and barriers to participation in virtual knowledge sharing communities of practice Journal of Knowledge Management, 7(1), 64 -77

Barnett, K., McCormick, J., \& Conners, R. (2001). Transformational Leadership in Schools - Panacea, Placebo or Problem? Journal of Education Administration, 39 (1), 24-46.

Bass, B. (1985). Leadership and Performance Beyond Expectations. New York: Free Press.

Bass, B., \& Avolio, B. (2000). The Multifactor Leadership Questionnaire Sampler Set: Technical Report, Leader Form, Rater Form, and Scoring Key for MLQ Form 5x-short, 2nd ed. California, US: Mind Garden.

Bass, B., \& Riggio, R. (2012). Transformational leadership, 2nd ed. US: Lawrence Erlbaum Associates, Inc.

Biggiero, L. (2012). Practice vs. Possession: Epistemological Implications on the Nature of Organizational Knowledge and Cognition. In Mora, M., Gelman, O., Steenkamp, A. L., and Raisinghani, M. (Eds.). Research methodologies, innovations and philosophies in software systems engineering and information systems, Chapter 5, pp.82-105, PA: IGI Global.

Bollinger, A., \& Smith, R. (2001). Managing organizational knowledge as a strategic asset Journal of Knowledge Management, 5(1), 8-18.

Braun, S., Peus, C., Weisweiler, S., \& Frey, D. (2013). Transformational leadership, job satisfaction, and team performance: A multilevel mediation model of trust. The Leadership Quarterly, Vol. 24, No.1, pp.270-283.

Carmeli, A., Gelbard, R. and Reiter-Palmon, R. (2013). Leadership, creative problem-solving capacity, and creative performance: The importance of knowledge sharing. Human Resource management, Vol.52, No. 1, pp.95-121.

Chang, J.-C. (2012). Factors that may mediate the relationship between transformational leadership and organizational innovation. African Journal of Business Management, 6(3), 1010-1018.

Chen, C., Huang, J., \& Hsiao, Y. (2010). Knowledge Management and innovativeness: the role of organizational climate and structure International Research Journal of Manpower, 31(8), 848870.

Chen, L. Y., \& Barnes, F. B. (2006). Leadership Behaviors and Knowledge Sharing in Professional Service Firms Engaged in Strategic Alliances. Journal of Applied Management and Enterperneruship 11(2), 51-69.

Cheng, E. (2012). Knowledge strategies for enhancing school learning capacity. International Journal of Educational Management, Vol. 26, No. 6, pp. 577-592. 
Chuang, C. H., Jackson, S.E. and Jiang, Y. (2016). Can knowledge-intensive teamwork be managed? Examining the roles of HRM systems, leadership, and tacit knowledge. Journal of management, Vol. 42, No.2, pp.524-554.

Daft, R. (1978). Organizational Innovation. Academy of Management Journal, 21(2), 193 - 210.

Dewar, R. D., \& Dutton, J. E. (1986). The adoption of radical and incremental innovations: An empirical analysis. Management science, 32(11), 1422-1433.

Eisenbeiß, S. A., \& Boerner, S. (2013). double-edged sword: Transformational leadership and individual creativity. British Journal of Management, Vol. (1), 54-68.

Fullwood, R., Rowley, J., \& Delbridge, R. (2013). Knowledge sharing amongst academics in UK universities. Journal of Knowledge Management, 17(1), 123-136.

García-Morales, V. J., Jiménez-Barrionuevo, M.M. and Gutiérrez-Gutiérrez, L. (2012). Transformational leadership influence on organizational performance through organizational learning and innovation. Journal of Business Research, Vol. 65, No.7, pp.1040-1050.

Glenn, D. (2003). Determining Sample Size, Florida Cooperative Extension Service, Institute of Food and Agricultural Sciences, University of Florida. 1-5.

Hair, J., Black, W., Babin, B., \& Anderson, R. (2010). Multivariate Data Analysis: A Global Perspective, 7th edition. New Jersey, US: Pearson Prentice Hall.

Han, S. H., Seo, G., Li, J., \& Yoon, S. W. (2016). The mediating effect of organizational commitment and employee empowerment: how transformational leadership impacts employee knowledge sharing intention. Human Resource Development International, Vol. 19, No. 2, pp.98-115.

Hau, Y. S., Kim, B., Lee, H., \& Kim, Y. G. (2013). The effects of individual motivations and social capital on employees' tacit and explicit knowledge sharing intentions. International Journal of Information Management, Vol. 33, No. 2, pp.356-366.

Herbst, T., \& Conradie, P. (2011). Leadership effectiveness in Higher Education: Managerial selfperceptions versus perceptions of others. Journal of Industrial Psychology, Vol. 37, No. 1, pp. $1-14$.

Hislop, D. (2013). Knowledge Management in Organizations- A critical Introduction, 3rd ed. Oxford, UK: Oxford University Press.

Hooff, V., \& Weenen, F. (2004). Committed to share: Commitment and CMC use as antecedents of knowledge sharing. Knowledge and Process Management, 11(1), 13-24.

Hung, R., Lien, B., Fang, S., \& Mclean, G. (2010). Knowledge as a facilitator for enhancing innovation performance through total quality management Total Quality Management, 21(4), 425-438.

Jahani, S., Ramaya, T., \& Effendi, A. (2011). Is reward system and leadership important in knowledge sharing among academics?. American Journal of Economics and Business Administration, 3(1), 87-94.

James, L., Guile, D., \& Unwin., L. (2016). Learning and Innovation in the Knowledge-based Economy: Beyond Clusters and Qualifications. Journal of Education and Work, 26(3), 243-266.

Jaskyte, K. (2004). Transformational leadership, organizational culture, and innovativeness in nonprofit organizations. Nonprofit Management and Leadership, 15(2), 153-168.

Jiang, Y., \& Chen, C. C. (2016). Integrating Knowledge Activities for Team Innovation Effects of Transformational Leadership. Journal of Management, dio: 0149206316628641.

Jung, D., Chow, C., \& Wu, A. (2003). The role of transformational leadership in enhancing organizational innovation: Hypotheses and some preliminary findings The Leadership Quarterly, 14, 525-544.

Leonardi, P. M. (2014). Social media, knowledge sharing, and innovation: Toward a theory of communication visibility. Information systems research, Vol. 25, No. 4, pp.796-816.

Li, G., Shang, Y., Liu, H., \& Xi, Y. (2014). Differentiated transformational leadership and knowledge sharing: A cross-level investigation. European Management Journal, 32(4), 554-563.

Liao, S., Fei, W., \& Chen, C. (2007). Knowledge sharing absorptive capacity, and innovation capability: An empirical study of Taiwan's knowledge intensive industries. Journal of Information Science, $33(3), 1-20$.

Lin, H. F. (2007). Knowledge sharing and firm innovation capability: An empirical study International Journal of Manpower, Vol. 28, No. 3/4 pp.315-337.

Lin, H. F., \& Lee, G. G. (2005). Impact of Organizational Learning and Knowledge Management Factors on E-business Adoption. Management Decision, 43(2), 171-188. 
Mansor, Z. D., Mustaffa, M., \& Salleh, L. M. (2015). Motivation and Willingness to Participate in Knowledge Sharing Activities Among Academics in a Public University. Procedia Economics and Finance, 31, 286-293.

Mathew, V. (2010). Service delivery through knowledge management in higher education. Journal of knowledge Management Practice, Vol.11, No. 3, pp. 1-14.

McClure, K. R. (2016). Building the Innovative and Entrepreneurial University: An Institutional Case Study of Administrative Academic Capitalism. The Journal of Higher Education, 87(4), 516543.

Mearns, M. (2012). Knowing what knowledge to share: Collaboration for community, research and wildlife. Expert Systems with Applications, Vol. 39, No. 10, pp.9892-9898.

Mittal, S., \& Dhar, R. L. (2015). Transformational leadership and employee creativity: mediating role of creative self-efficacy and moderating role of knowledge sharing. Management Decision, Vol. 53, No. 5, pp.894-910.

Mohamad, M. S. (2012). Transformational Leadership and Employees' Job Satisfaction and Commitment: A Structural Equation Investigation. Journal of American Science, 8(7), 11-19.

MOHESR. (2012). The annual guidebook of the Ministry of Higher Education and Scientific Research Baghdad: Higher Education Press.

Nguyen, H., \& Mohamed, S. (2011). Leadership behaviors, organizational culture and knowledge management practices: An empirical investigation. Journal of Management Development, 30(2), 206-221.

Nijstad, B. A., Berger-Selman, F., \& De Dreu, C. K. (2014). Innovation in top management teams: Minority dissent, transformational leadership, and radical innovations. European journal of work and organizational psychology, Vol. 23, No. 2, pp.310-322.

Northouse, P. (2012). Introduction to leadership: Concepts and practice, 2nd ed. USA: Los Angeles SAGE Publication.

Noruzy, A., Dalfard, V. M., Azhdari, B., Nazari-Shirkouhi, S., \& Rezazadeh, A. (2013). Relations between transformational leadership, organizational learning, knowledge management, organizational innovation, and organizational performance: an empirical investigation of manufacturing firms. The International Journal of Advanced Manufacturing Technology, Vol. 64, No. 5-8, pp.1073-1085.

Obendhain, A., \& Johnson, W. (2004). Product and process innovation in service organizations: The influence of organizational culture in higher education institutions. The Journal of Applied Management and Entrepreurship, 9(3), 91- 113.

Perri. (1993). Innovation by nonprofit organizations: policy and research issues. Nonprofit Management \& Leadership, Vol. 3, No. 4, pp. 397-414.

Pounder, J. (2009). Transformational classroom leadership: A basis for academic staff development. Journal of Management Development, Vol. 28, No. 4, pp. 317-325.

Rafferty, A., \& Griffin, M. (2004). Dimensions of transformational leadership: Conceptual and empirical extension. The Leadership Quarterly, 15, 329 -354.

Redmond, M., \& Mumford, M. (1993). Putting Creativity to Work: Effects of Leader Behavior on Subordinate Relativity. Organizational Behavior and Human Decision Processes, 55 (1), 120 151.

Ritala, P., Olander, H., Michailova, S., \& Husted, K. (2015). Knowledge sharing, knowledge leaking and relative innovation performance: An empirical study. Technovation, Vol. 35, pp.22-31.

Sagnak, M. (2012). The empowering leadership and teachers' innovative behavior: The mediating role of innovation climate. African Journal of Business Management, 6(4), 1635-1641.

Schmitt, A., D. N. , Hartog, D., \& Belschak, F. D. (2016). Transformational Leadership and Proactive Work Behavior: A Moderated Mediation Model Including Work Engagement and Job Strain. Journal of Occupational and Organizational Psychology, 89(3), 588-610.

Shao, Z., Feng, Y., \& Liu, L. (2012). The mediating effect of organizational culture and knowledge sharing on transformational leadership and Enterprise Resource Planning systems success: An empirical study in China. Computers in Human Behavior, Vol. 28, No. 6, pp.2400-2413.

Sikhi, A. H. (2008). Study the system in Iraq, Report. Baghdad, Iraq: Higher Education Press.

Smith, D. (2009). Exploring Innovation, 2nd ed. London: McGraw-Hill Higher Education. 
Srivastava, A., Bartol, K., \& Locke, E. (2006). Empowering leadership in management teams: Effects on knowledge sharing, efficacy, and performance Academy of Management Journal, Vol.49, No. 6, PP. 1239-1251.

Tan, C. N. L. (2016). Enhancing Knowledge Sharing and Research Collaboration among Academics: The Role of Knowledge Management. Higher Education, 71(4), 525-556.

Theyel, G., \& Hofmann, K. H. (2015). Environmental practices and innovation performance of US small and medium-sized manufacturers. Journal of Manufacturing Technology Management, Vol. 26, No.3, pp.333-348.

Tidd, J., \& Bessant, J. (2011). Managing innovation: Integrating, technological, market and organizational change, 4th ed. London: John Wiley \& Sons.

Tims, M., Bakker, A. B., \& Xanthopoulou, D. (2011). Do transformational leaders enhance their followers' daily work engagement? The Leadership Quarterly, Vol. 22, No. 1, pp.121-131.

Trott, P. (2008). Innovation management and new product development, 4th ed. London: Prentice Hall.

Tsai, C., Huang, K., \& Kao, c. (2001). The relationships among organizational factors, creativity of organizational members and innovation capability. Journal of management, 18, 527-566.

UNESCO. (2003). Situation analysis of education in Iraq. United Nations Educational Scientific and Cultural Organization - Division of educational polices and strategies, pp 1-127, Paris.

UNESCO. (2004). Iraq, education in transition needs and challenges. United Nations Educational Scientific and Cultural Organization - Division of educational polices and strategies, Paris, France, pp.1-151.

Vaccaro, I. G., Jansen, J. J. P., Bosch, F. A. J. V. D., \& Volberda, H. W. (2012). Management Innovation and Leadership: The moderating role of organizational size. Journal of Management Studies, 49(1), 28-59.

Von Krogh, G., Nonaka, I., \& Rechsteiner, L. (2012). Leadership in organizational knowledge creation: A review and framework. Journal of Management Studies, Vol. 49, No.1, pp.240-277.

Walker, R. (2007). An empirical evaluation of innovation types and organizational and environmental characteristic: Towards a configuration framework. Journal of Public Administration Research and Theory, 17, 591-615.

Wang, Z., \& Wang, N. (2012). Knowledge sharing, innovation and firm performance. Expert Systems with Applications, Vol. 39, No.10, pp. 8899 - 8908.

Weng, R. H., Huang, C. Y., Chen, L. M., \& Chang, L. Y. (2015). Exploring the impact of transformational leadership on nurse innovation behavior: a cross-sectional study. Journal of nursing management, Vol. 23, No. 4, pp.427-439.

Yukl, G. (2013). Leadership in organizations, 8th ed., New Jersey, U.S. Upper Saddle River, Pearson Education.

Zheng, W., Yang, B., \& Mclean, G. (2009). Linking organizational culture, structure, strategy, and organizational effectiveness: Mediating role of knowledge management Journal of Business Research, vol. 6 pp 1-9.

Zhou, K. Z., \& Li, C. B. (2012). How knowledge affects radical innovation: Knowledge base, market knowledge acquisition, and internal knowledge sharing. Strategic Management Journal, Vol. 33, No. 9, pp.1090-1102.

Zwain, A., A., Teong, L., K., \& Othman, S. N. (2012). Knowledge management processes and academic performance in Iraqi HEIs: An empirical investigation. International Journal of Academic Research in Business and Social Sciences, Vol. 2, No. 6, pp.273-293.

Appendix: Questionnaire items

ANSERT TABLE APPENDIX HERE 


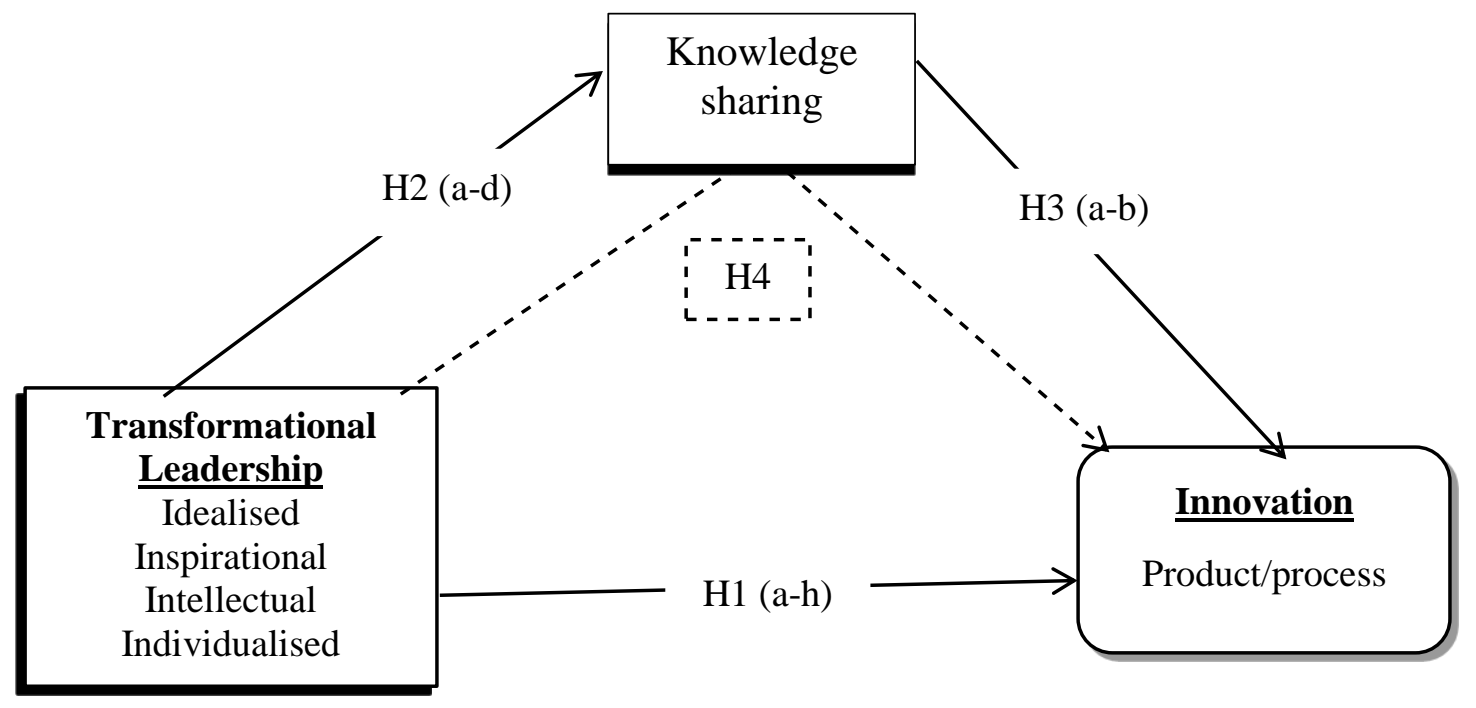

Fig. 1. Hypothetical model 
Table 1: Profiles of valid respondents

\begin{tabular}{|c|c|c|c|}
\hline \multicolumn{2}{|c|}{ Characteristic } & Frequency & Percentage \\
\hline Gender & $\begin{array}{c}\text { Male } \\
\text { Female }\end{array}$ & $\begin{array}{l}114 \\
136\end{array}$ & $\begin{array}{l}45.6 \\
54.4\end{array}$ \\
\hline Marital status & $\begin{array}{c}\text { Single } \\
\text { Married } \\
\text { Divorced } \\
\text { Widowed }\end{array}$ & $\begin{array}{c}86 \\
113 \\
9 \\
42\end{array}$ & $\begin{array}{l}34.4 \\
45.2 \\
3.6 \\
16.8\end{array}$ \\
\hline Age & $\begin{array}{c}<29 \\
30-39 \\
40-49 \\
50-59 \\
>60\end{array}$ & $\begin{array}{c}8 \\
29 \\
74 \\
84 \\
55\end{array}$ & $\begin{array}{c}3.2 \\
11.6 \\
29.6 \\
33.6 \\
22\end{array}$ \\
\hline Tenure & $\begin{array}{c}<10 \text { years } \\
11-15 \\
16-20 \\
21-25 \\
>26\end{array}$ & $\begin{array}{l}11 \\
26 \\
65 \\
79 \\
69\end{array}$ & $\begin{array}{c}4.4 \\
10.4 \\
26 \\
31.6 \\
27.6\end{array}$ \\
\hline $\begin{array}{l}\text { Highest academic } \\
\text { qualification }\end{array}$ & $\begin{array}{c}\text { Bachelor } \\
\text { Higher Diploma } \\
\text { Master } \\
\text { Doctorate }\end{array}$ & $\begin{array}{c}5 \\
7 \\
73 \\
165\end{array}$ & $\begin{array}{c}2 \\
2.8 \\
29.2 \\
66\end{array}$ \\
\hline
\end{tabular}

Table 2. Results of CFA

\begin{tabular}{|c|c|c|c|c|c|}
\hline Constructs & Item & Loading & AVE & CR & $\alpha$ \\
\hline Idealised & ID1 & 0.817 & 0.71 & 0.90 & 0.90 \\
Influenced & ID2 & 0.834 & & & \\
(F1) & ID3 & 0.907 & & & \\
\hline
\end{tabular}




\begin{tabular}{|c|c|c|c|c|c|}
\hline $\begin{array}{c}\text { Inspirational } \\
\text { motivation } \\
\text { (F2) }\end{array}$ & $\begin{array}{l}\text { IM5 } \\
\text { IM6 } \\
\text { IM7 } \\
\text { IM8 }\end{array}$ & $\begin{array}{l}0.745 \\
0.892 \\
0.871 \\
0.849\end{array}$ & 0.72 & 0.89 & 0.88 \\
\hline $\begin{array}{l}\text { Intellectual } \\
\text { stimulation } \\
\text { (F3) }\end{array}$ & $\begin{array}{c}\text { IS9 } \\
\text { IS10 } \\
\text { IS11 } \\
\text { IS12 }\end{array}$ & $\begin{array}{l}0.759 \\
0.878 \\
0.888 \\
0.871\end{array}$ & 0.73 & 0.90 & 0.90 \\
\hline $\begin{array}{l}\text { Individualised } \\
\text { Consideration } \\
\text { (F4) }\end{array}$ & $\begin{array}{c}\text { IC13 } \\
\text { IC14 } \\
\text { IC15 } \\
\text { IC16 }\end{array}$ & $\begin{array}{l}0.856 \\
0.869 \\
0.812 \\
0.816\end{array}$ & 0.70 & 0.87 & 0.87 \\
\hline $\begin{array}{l}\text { Knowledge } \\
\text { sharing } \\
\text { (F5) }\end{array}$ & $\begin{array}{l}\text { KD17 } \\
\text { KD18 } \\
\text { KD19 } \\
\text { KD20 } \\
\text { KC21 } \\
\text { KC22 } \\
\text { KC23 } \\
\text { KC24 }\end{array}$ & $\begin{array}{l}0.848 \\
0.887 \\
0.832 \\
0.845 \\
0.856 \\
0.890 \\
0.847 \\
0.870\end{array}$ & 0.76 & 0.95 & 0.95 \\
\hline $\begin{array}{c}\text { Product } \\
\text { innovation } \\
\text { (F6) }\end{array}$ & $\begin{array}{l}\text { PD25 } \\
\text { PD26 } \\
\text { PD27 } \\
\text { PD28 }\end{array}$ & $\begin{array}{l}0.908 \\
0.948 \\
0.818 \\
0.720\end{array}$ & 0.74 & 0.91 & 0.91 \\
\hline $\begin{array}{c}\text { Process } \\
\text { innovation } \\
(\mathrm{F} 7)\end{array}$ & $\begin{array}{l}\text { PC29 } \\
\text { PC30 } \\
\text { PC31 } \\
\text { PC32 }\end{array}$ & $\begin{array}{l}0.920 \\
0.814 \\
0.844 \\
0.748\end{array}$ & 0.68 & 0.88 & 0.88 \\
\hline
\end{tabular}

Note: $\mathrm{AVE}=$ average variance extracted, $\mathrm{CR}=$ composite reliability, $\alpha=$ Cronbach's alpha

Table 3. Means, Standard Deviations and Discriminant Validity Analysis

\begin{tabular}{|l|c|c|c|c|c|c|c|c|c|}
\hline \multicolumn{1}{|c|}{ Construct } & Mean & SD & 1 & 2 & 3 & 4 & 5 & 6 & 7 \\
\hline 1-Idealised & 3.299 & 0.879 & 0.71 & & & & & & \\
\hline 2-Inspirational & 3.302 & 0.860 & $0.34^{*}$ & 0.72 & & & & & \\
\hline 3-Intellectual & 3.418 & 0.885 & $0.33^{*}$ & $0.15^{* *}$ & 0.73 & & & & \\
\hline 4-Individualised & 3.426 & 0.889 & $0.24^{*}$ & $0.32^{*}$ & $0.19^{* *}$ & 0.70 & & & \\
\hline
\end{tabular}




\begin{tabular}{|l|c|c|c|c|c|c|c|c|c|}
\hline 5-Knowledge sharing & 3.466 & 0.897 & $0.12^{* *}$ & $0.28^{*}$ & $0.44^{*}$ & $0.39^{*}$ & 0.76 & & \\
\hline 6-product innovation & 3.290 & 0.868 & $0.26^{*}$ & $0.34^{*}$ & $0.33^{*}$ & $0.44^{*}$ & $0.32^{*}$ & 0.74 & \\
\hline 7-Process innovation & 3.352 & 0.884 & $0.26^{*}$ & $0.35^{*}$ & $0.34^{*}$ & $0.46^{*}$ & $0.42^{*}$ & $0.22^{*}$ & 0.68 \\
\hline
\end{tabular}

Note: $\mathrm{N}=250, \mathrm{SD}=$ standard deviation, $\mathrm{p}^{*}<0.05, \mathrm{p}^{* *}<0.01$

Table 4. Overall fit indices of the CFA of the model

\begin{tabular}{|c|c|c|c|c|}
\hline Fit index & Transformational leadership & Knowledge sharing & Innovation & Recommended criteria \\
\hline$\chi^{2} / \mathrm{df}$ & 1.323 & 1.520 & 1.348 & $\leq 2-5$ \\
\hline GFI & 0.922 & 0.932 & 0.962 & $\geq 0.90$ \\
\hline RMSEA & 0.038 & 0.049 & 0.048 & $<0.05-0.08$ \\
\hline NFI & 0.945 & 0.992 & 0.980 & $\geq 0.90$ \\
\hline CFI & 0.988 & 0.973 & 0.986 & $\geq 0.90$ \\
\hline
\end{tabular}

Table 5. Direct Effects Obtained using SEM

\begin{tabular}{|c|c|c|c|c|}
\hline \multicolumn{2}{|c|}{ Hypothesis } & Hypothesis path & Estimate & Results \\
\hline \multirow{11}{*}{ H1 } & H1a & Idealised $\rightarrow$ product & $0.214^{*}$ & Supported \\
\hline & $\mathrm{H} 1 \mathrm{~b}$ & Inspirational $\rightarrow$ product & $0.263^{*}$ & Supported \\
\hline & H1c & Intellectual $\rightarrow$ product & $0.301 * *$ & Supported \\
\hline & H1d & Individualised $\rightarrow$ product & $0.352 * *$ & Supported \\
\hline & H1(a-d) & Transformational leadership $\rightarrow$ product & $0.289 * * *$ & Supported \\
\hline & H1e & Idealised $\rightarrow$ process & $0.243^{*}$ & Supported \\
\hline & H1f & Inspirational $\rightarrow$ process & $0.265^{*}$ & Supported \\
\hline & H1g & Intellectual $\rightarrow$ process & $0.307 *$ & Supported \\
\hline & $\mathrm{H} 1 \mathrm{~h}$ & Individualised $\rightarrow$ process & $0.354 * *$ & Supported \\
\hline & $\mathrm{H} 1$ & Transformational leadership $\rightarrow$ process & $0.301 * *$ & Supported \\
\hline & $\mathrm{H} 1(\mathrm{a}-\mathrm{h})$ & Transformational leadership $\rightarrow$ innovation & $0.295^{*}$ & Supported \\
\hline \multirow{5}{*}{$\mathrm{H} 2$} & $\mathrm{H} 2 \mathrm{a}$ & Idealised $\rightarrow$ knowledge sharing & $0.570 *$ & Supported \\
\hline & $\mathrm{H} 2 \mathrm{~b}$ & Inspirational $\rightarrow$ knowledge sharing & $0.524 *$ & Supported \\
\hline & $\mathrm{H} 2 \mathrm{c}$ & Intellectual $\rightarrow$ knowledge sharing & $0.790 * *$ & Supported \\
\hline & $\mathrm{H} 2 \mathrm{~d}$ & Individualised $\rightarrow$ knowledge sharing & $0.635 * * *$ & Supported \\
\hline & $\mathrm{H} 2(\mathrm{a}-\mathrm{d})$ & $\mathrm{TL} \rightarrow$ knowledge sharing & $0.629 * *$ & Supported \\
\hline \multirow{2}{*}{$\mathrm{H} 3$} & $\mathrm{H} 3 \mathrm{a}$ & knowledge sharing $\rightarrow$ product & $0.701 * *$ & Supported \\
\hline & $\mathrm{H} 3 \mathrm{~b}$ & knowledge sharing $\rightarrow$ process & $0.745^{* *}$ & Supported \\
\hline
\end{tabular}




\begin{tabular}{|l|c|c|c|c|}
\hline & H3(a-b) & knowledge sharing $\rightarrow$ innovation & $0.723 * *$ & Supported \\
\hline Fit index & $\chi^{2} / \mathrm{df}=1.252, \mathrm{GFI}=0.914$, RMSEA $=0.04, \mathrm{NFI}=0.940, \mathrm{CFI}=0.981, \mathrm{PNFI}=0.872$ \\
\hline
\end{tabular}

Table 6. Results of direct, indirect, and total effects

\begin{tabular}{|c|c|c|c|c|c|c|}
\hline \multirow{2}{*}{ Hypothesis } & \multicolumn{2}{|c|}{ Predictor } & Dependent & Effect & Estimate & $\begin{array}{c}\text { Total } \\
\text { effect }\end{array}$ \\
\cline { 1 - 5 } H1(a-h) & Transformational leadership & $\longrightarrow$ & Innovation & Direct & 0.295 & \multirow{2}{*}{0.788} \\
\cline { 2 - 5 } H4 & $\begin{array}{c}\text { Transformational leadership + } \\
\text { knowledge sharing }\end{array}$ & & Innovation & Indirect & 0.493 & \\
\cline { 2 - 5 } & & & &
\end{tabular}

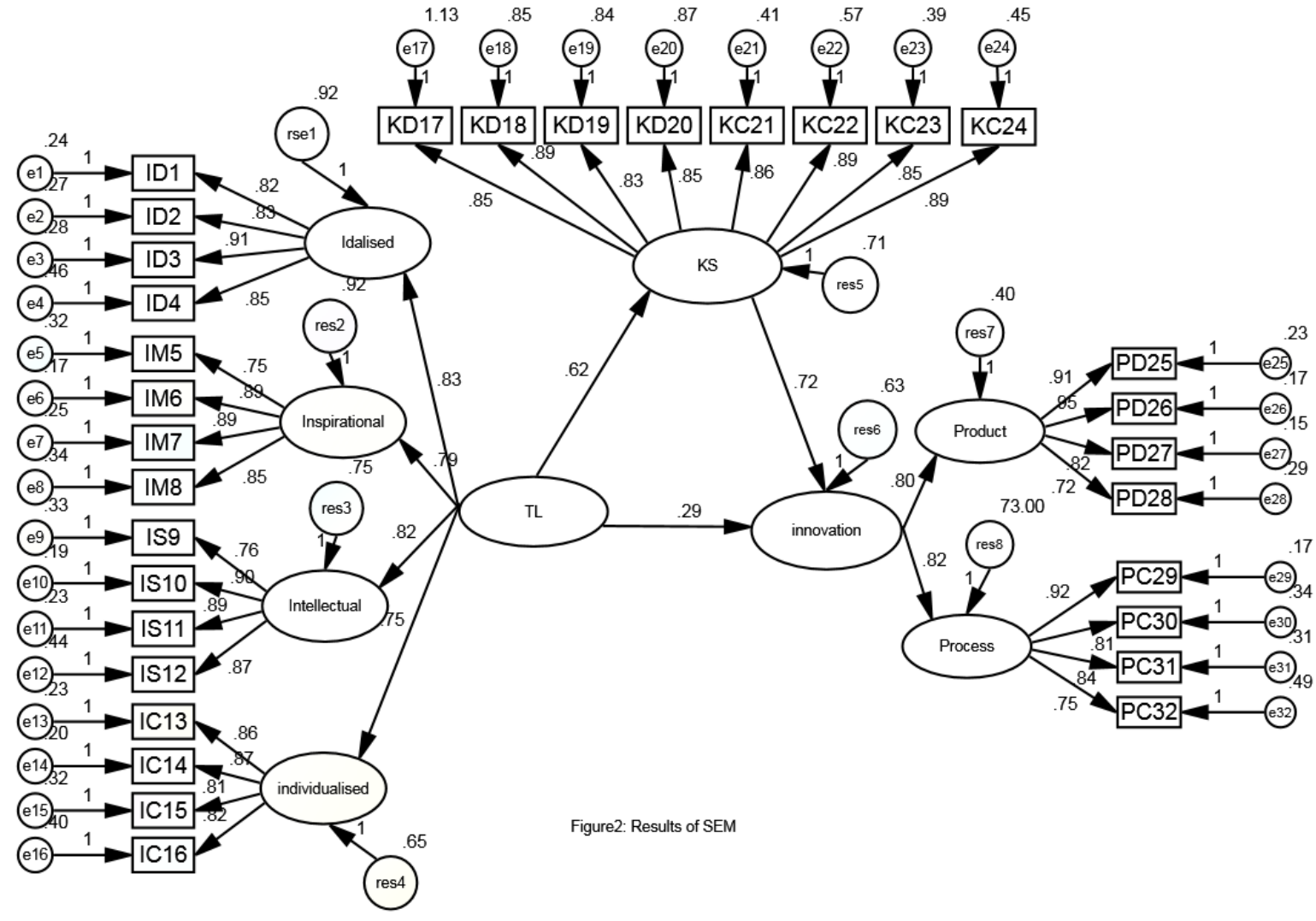

Figure 2. Results of SEM 
Appendix: questionnaire items

\begin{tabular}{|c|c|}
\hline Construct & Item \\
\hline \multirow[t]{3}{*}{$\frac{\text { Transformational }}{\underline{\text { leadership }}}$} & Acts in ways that build my respect. * \\
\hline & Instils pride in being associated with him/ her \\
\hline & Talks about his/ her important values and beliefs. $*$ \\
\hline \multirow[t]{4}{*}{ Idealize influence } & Goes beyond self-interest for the good of the group \\
\hline & Considers the moral and ethical consequences of decisions. ${ }^{*}$ \\
\hline & Emphasises the importance of having a collective sense of mission \\
\hline & Displays a sense of power and confidence \\
\hline \multirow{5}{*}{$\begin{array}{l}\text { Inspirational } \\
\text { motivation }\end{array}$} & Talks optimistically about the future \\
\hline & Talks enthusiastically about what needs to be accomplished \\
\hline & Articulates a compelling vision of the future. $*$ \\
\hline & Expresses confidence that goals will be achieved \\
\hline & Develops a team attitude and spirit among members of staff \\
\hline \multirow{5}{*}{$\begin{array}{l}\text { Intellectual } \\
\text { simulation }\end{array}$} & $\begin{array}{l}\text { Re-examine critical assumptions to question whether they are } \\
\text { appropriate }\end{array}$ \\
\hline & Gets me to look at problems from many different angles \\
\hline & Suggests new ways of looking at how to complete assignments. * \\
\hline & Seeks different perspectives when solving problems \\
\hline & $\begin{array}{l}\text { Encourages me to rethink ideas that have never been questioned } \\
\text { before }\end{array}$ \\
\hline \multirow{4}{*}{$\begin{array}{l}\text { Individualised } \\
\text { consideration }\end{array}$} & Spends time teaching and coaching \\
\hline & Treats me as an individual rather than just as a member of a group \\
\hline & $\begin{array}{l}\text { Considers me as having different needs, abilities and aspirations to } \\
\text { others }\end{array}$ \\
\hline & Helps me to develop my strengths \\
\hline \multirow[t]{2}{*}{ Knowledge sharing } & $\begin{array}{l}\text { Knowledge sharing with colleagues is considered normal outside of } \\
\text { my department. }\end{array}$ \\
\hline & $\begin{array}{l}\text { Knowledge sharing among colleagues is considered normal in my } \\
\text { department. * }\end{array}$ \\
\hline
\end{tabular}




\begin{tabular}{|c|c|}
\hline & $\begin{array}{l}\text { When I have learned something new, I tell colleagues outside of my } \\
\text { department about it. * }\end{array}$ \\
\hline & $\begin{array}{l}\text { When they have learned something new, my colleagues within my } \\
\text { department tell me about it. }\end{array}$ \\
\hline & $\begin{array}{l}\text { I share information about teaching profession with my colleagues in } \\
\text { the University. } *\end{array}$ \\
\hline & $\begin{array}{l}\text { I share information about administrative issues with my colleagues } \\
\text { in the University. * }\end{array}$ \\
\hline & $\begin{array}{l}\text { When I have learned something new regarding teaching profession, } \\
\text { I tell my colleagues in my department about it. }\end{array}$ \\
\hline & $\begin{array}{l}\text { When they have learned something new, colleagues outside of my } \\
\text { department tell me about it }\end{array}$ \\
\hline & $\begin{array}{l}\text { I share information I have with colleagues within my department } \\
\text { when they ask for it. }\end{array}$ \\
\hline & $\begin{array}{l}\text { Colleagues in my university share information about teaching } \\
\text { profession with me. }\end{array}$ \\
\hline & $\begin{array}{l}\text { Colleagues within my department share knowledge with me, when I } \\
\text { ask them about it. * }\end{array}$ \\
\hline & $\begin{array}{l}\text { Colleagues within my department tell me what their skills are, when } \\
\text { I ask them about it. } *\end{array}$ \\
\hline & $\begin{array}{l}\text { I share my skills with colleagues outside of my department, when } \\
\text { they ask me to. * }\end{array}$ \\
\hline & $\begin{array}{l}\text { I share my skills with colleagues within my department, when they } \\
\text { ask for it. }\end{array}$ \\
\hline & $\begin{array}{l}\text { I share information I have with colleagues outside of my department, } \\
\text { when they ask me to. }\end{array}$ \\
\hline & $\begin{array}{l}\text { Colleagues in my university share information about administrative } \\
\text { issues with me. } *\end{array}$ \\
\hline \multirow{5}{*}{ Product innovation } & Our university is delivering new courses for members of staff. \\
\hline & $\begin{array}{l}\text { Our university constantly emphasises development and doing } \\
\text { research projects. * }\end{array}$ \\
\hline & $\begin{array}{l}\begin{array}{l}\text { Our university often develops new teaching materials and } \\
\text { methodologies. }\end{array} \\
\end{array}$ \\
\hline & $\begin{array}{l}\text { Our university often develops new programmes/ services for } \\
\text { members of staff and students. }\end{array}$ \\
\hline & $\begin{array}{l}\text { Our university is extending its programmes/ services to new groups } \\
\text { of employees not previously served by the university/institute. }\end{array}$ \\
\hline \multirow{5}{*}{ Process innovation } & $\begin{array}{l}\text { Our university is developing new training programmes for staff } \\
\text { members. }\end{array}$ \\
\hline & $\begin{array}{l}\text { Our university encourages teamwork and good working } \\
\text { relationships between staff members. * }\end{array}$ \\
\hline & $\begin{array}{l}\text { Our university is implementing an incentive system (i.e. higher } \\
\text { salaries, bonuses, --) to encourage members of staff to come up with } \\
\text { innovative ideas. }\end{array}$ \\
\hline & $\begin{array}{l}\text { Our university often develops new technology (internet, databases, - } \\
--) \text { to improve the educational process. * }\end{array}$ \\
\hline & $\begin{array}{l}\text { Our university often uses new technology to improve the educational } \\
\text { process. }\end{array}$ \\
\hline
\end{tabular}




\begin{tabular}{|l|l|}
\hline & $\begin{array}{l}\text { New multimedia software is used by this university for educational } \\
\text { purposes and administrative operations. * }\end{array}$ \\
\cline { 2 - 3 } & $\begin{array}{l}\text { This university is implementing a reward system (i.e. promotions, } \\
\text { thank----yous) to encourage members of staff to come up with } \\
\text { innovative ideas. * }\end{array}$ \\
\cline { 2 - 3 } & $\begin{array}{l}\text { Our university is trying to bring in new equipment (i.e. computers) } \\
\text { to facilitate educational operations and work procedures. }\end{array}$ \\
\hline
\end{tabular}

Note: $\left.{ }^{*}\right)$ Refers to the item deleted after running convergent validity test 